\title{
A factor analysis of an instrument for measuring physical abuse experience of students at school
}

\author{
${ }^{* 1}$ Safrudin Amin; ${ }^{2}$ Badrun Kartowagiran; ${ }^{3}$ Pracha Inang \\ ${ }^{1}$ Faculty of Literature and Culture, Universitas Khairun \\ ${ }^{1}$ Jl. Pertamina Kampus II Unkhair Gambesi Kota Ternate Selatan, 97719, Indonesia \\ ${ }^{2}$ Faculty of Engineering, Universitas Negeri Yogyakarta \\ Jl. Colombo No. 1, Karangmalang, Depok, Sleman 55281, Yogyakarta, Indonesia \\ ${ }^{3}$ Faculty of Education, Burapha University \\ 169 Longhaad Bangsaen Road, Saensook, Mueang, ChonBuri 20131, Thailand \\ ${ }^{*}$ Corresponding Author. E-mail: safrudinamin@gmail.com \\ Submitted: 24 May 2018 | Revised: 04 August 2018 | Accepted: 08 August 2018
}

\begin{abstract}
Violence in schools is increasingly reported by the mass media. It indicates that its prevalence is escalating. An instrument which has a proper psychometric property is needed to investigate the phenomenon. The study aims to develop an instrument for measuring physical abuse experienced by students in schools and explore the construct of the instrument. To pursue those objectives, the content validitity, construct validity, and reliability analysis on the developed instrument were measured. Its content validity was confirmed through expert judgment, construct validity was proven through exploratory factor analysis, and reliability was estimated through Cronbach's alpha coefficient. Experts considered that the content of all items were relevant, though they also suggested some improvement in wordings for greater clarity. The exploratory factor analysis on 31 items indicates that seven items need to be dropped and 24 items are divided into three factors called (1) victimized by friends with the loading factor ranging from 0.44 to 0.69 , (2) victimizing friends with the loading factor ranging from 0.45 to 0.66 , and (3) being victimized by teachers with the loading factor ranging from 0.57 to 0.68 . The reliability of the test was 0.874 . Based on this result, the developed instruments consist of three factors with good validity and reliability.
\end{abstract}

Keywords: physical abuse, student, school, validity, reliability

\section{Introduction}

Studies on abuses against children have been conducted by individuals as well as organizations. Research findings show the increasing incidents of violence against children in this country. This alarming trend, however, has not attracted serious attention from those in power (Idris, 2015). One of the most important concerns of violence against children is the violence which takes place at school.

A survey conducted by Plan International and International Center for Research on Women (ICRW) shows $84 \%$ of Indonesian children experience abuse in school. This result is higher than the trend in Asian region which is
70\% (Qodar, 2015). The data released in June 2015 by the Commission of Indonesian Children Protection (Komisi Perlindungan Anak Indonesia - KPAI) show that from 2011 to April 2015, violence against children grew significantly. In 2012, a survey in nine provinces demonstrated that $87.6 \%$ students experienced abuse in school (Setyawan, 2015). The data published by KPAI in November 2017 show that violence against children in school is mounting. As many as $84 \%$ students, or eight out of ten students, have ever experienced abuse in school. Among them, 45\% male students report that their teachers or school staff are the persecutors (Setyawan, 2017). 
Before proceeding further, it is important to assert the terms 'violence', 'abuse', 'maltreatment', 'bullying', and the like. Many studies by organizations or individuals have used the terms interchangeably although they refer to the same phenomena, or some concepts are treated as part of other concepts. The UN Secretary-General's Study defines violence against children in line with article 19 of the CRC which treats 'abuse', 'maltreatment', and 'exploitation' as parts of violence (UNICEF, 2014b, p. 2). World Health Organization (WHO) equates the concept of 'abuse' and 'maltreatment' (UNICEF, 2014a, p. 19). It defines child abuse or maltreatment:

'...constitutes all forms of physical and/or emotional ill-treatment, sexual abuse, neglect or negligent treatment or commercial or other exploitation, resulting in actual or potential harm to the child's health, survival, development or dignity in the context of a relationship of responsibility, trust or power'

UNICEF (2014a, p. 21) made inventory of studies on violence against children and grouped together studies using different terms such as 'physical violence', 'physical abuse', and 'physical maltreatment' into one category that is physical dimension of violence for the reason that they are dealing with roughly the same phenomena. Here, 'violence', 'abuse', and 'maltreatment' are regarded as identical.

UNICEF (2014a, p. 21) also includes 'bullying' as part of 'violence'. Nansel et al. (2001) define bullying as aggressive behavior which is intended to harm or disturb, committed by a more powerful person or group to those who are powerless, and it occurs repeatedly over time. The characters of intention to harm others and asymmetric power between the persecutors and their victims overlaps with the definition of 'violence' held by WHO which also emphasizes the intention to harm others by using power (UNICEF, 2014a, p. 19).

Nansel et al. (2001, p. 2094) also state that bullying behavior could be verbal, psychological, or even physical. Rivers and Smith (1994, p. 362) find that physical abuse in bullying could be in the forms of '..directphysical behaviours such as hitting, kicking, and stealing'. NSPCC (2016, p. 7) uses the term 'physical bullying' to refer to kicking, hitting, biting, pinching, hair pulling, and making threats'. This clearly shows that 'bullying' is equal to 'physical abuse', and it is reasonable that UNICEF includes 'bullying' as a part of 'violence'.

This research adopts WHO's definition of child abuse mentioned earlier since it offers a notion that abuse or maltreatment does not always result in actual harm but could also be in a form of potential harm. However, as we go further to discuss physical abuse in this section, it will become clearer that our point of emphasis is not on the effects of violence acts as asserted by WHO, but on the acts of violence themselves.

Apart from the conceptual problem, in general, many experts come to a conclusion that any kinds of abuse against children committed either by teachers or fellow students in school, or abuse taking place outside school, has a destructive impact on children's academic performance in school, in addition to other forms of negative impacts faced by the children. Hyman and Perone (1998, p. 19) explain that many studies have found that children who experience psychological maltreatment during their preschool and school age have lower academic performance. Likewise, their ability and social competence are also low, compared to those students who have not experienced such maltreatment. This is in line with Ajema, Muraya, Karuga, and Kiruki (2016, p. 2) who conclude that violence in school and associated fear, anxiety, and injuries contribute to poor education and health outcomes. According to them, violence in school can lead to the destruction of children's capacity and potentials to take advantages maximally during their education processes because they tend to be absent, unwilling to continue their study, and weakly motivated to get academic achievement.

Nansel et al. (2001) summarize that bullying has a significant correlation with academic achievement. Both the persecutors and victims show low academic achievement compared to those students who are not involved in abuse. Quoting some studies, Simpson (2015, p. 18) also confirms that abuse such as 
bullying can badly affect student's academic performances. Cohn and Canter (2003) find that bullying causes the victims to face difficulties in dealing with academic challenges in school, and both perpetrators and victims have strong correlation with drop-out incidence. In addition, based on some studies, United Nations Secretary-General's Study (2006, p. 130) also synthesizes that 'physical and psychological punishment, verbal abuse, bullying and sexual violence in schools are repeatedly reported as the reasons for absenteeism, dropping-out, and lack of motivation for academic achievement'.

So far, violence against children has been reflected in various terms, such as 'child abuse', 'violence against children', 'maltreatment', 'bullying', and some more. However, the aspects of abuse are rather well-accepted by different organizations and scholars. Choo, Dunne, Marret, Fleming, and Wong (2011) divide child abuses or the victimization of children into four categories: physical abuse, sexual abuse, emotional abuse, and neglect. In line with that notion, Law No. 35 of 2014 of Republic of Indonesia also states that the aspects of child abuse are physical, psychological, sexual, and negligent.

Moreover, experts provide the detailed aspect of physical abuse. Muthmainnah (2014, p. 446) states that 'physical abuse occurs when an adult (parent, educator, caregiver, etc.) injures a child physically such as hitting, pinching, kicking, slapping, etc.' Clark, Clark, and Adamec (2007, p. 203) define physical abuse as 'an act of commission by a parent or other persons that may or may not be accidental and that results in physical injury.' Besides, WHO claims that:

\section{Dhysical abuse of a child is that which results in actual or potential harm from an interaction or lack of an interaction, which is reasonably within the control of a parent or person in a position of responsibility, power or trust. There may be a sigle or repeated incidents' (UNICEF, 2014a, p. 20).}

The adjective term 'physical' in 'physical abuse' has allowed the birth of various derivative terms such as physical violence, physical assault, physical harassment, physical victim- ization, physical maltreatment, physical bullying, and the like, but all refer to the threats or harmful actions that make the victim's physicality a target, whether it causes physical injury or not. The definition emphasizes on the acts of violence or abuses rather than the results of the acts. This position is fully reflected in the instrument developed in this study.

In the context of research on child abuse in school, this instrument development is considered to be crucial for two reasons. First, there is a clear evidence of the increasing number of child abuse in school, including physical abuse, which has potential destructive impacts on students. Second, studies on violence in school frequently do not make public the detailed psychometric properties of their instruments. In order to be useful, the instrument developed must have good validity and reliability to ensure its accuracy and internal consistency.

\section{Method}

This study selected 584 respondents, who were grade IX students of three junior high schools in Ternate, North Maluku, Indonesia. They were asked to fill out a questionnaire concerning their experiences of physical abuse in their schools. Out of the total sample, 577 responses were feasible to be analyzed. This research adopted several items from previous studies (Choo et al., 2011; Straus, Hamby, Boney-McCoy, \& Sugarman, 1996; Straus, Hamby, Finkelhor, Moore, \& Runyan, 1998; UNICEF, 2014a), tailored and modified them to meet its specific objectives.

The items in the questionnaire were ranked and scored using a modified Likert scale. The respondents were asked to choose one of the responses offered. The response categories were: never $=1$, seldom $=2$, sometimes $=3$, frequently $=4$, and always $=5$. All items are cast in positive terms. The 31 items addressed three different aspects assumed to be the aspects of child physical abuse. The three aspects are abuses committed by teachers, abuse committed by fellow students, and abuse committed by respondents to other students.

The content validity was confirmed through expert judgment to ensure its rele- 
vance to the construct to be measured. Three reviewers reviewed the first draft of the instrument and provided their input to improve the quality of the instrument. Each item was accompanied by five alternative responses and each reviewer had to score the item by choosing an alternative answer ranging from $1=$ irrelevant, $2=$ rather relevant, $3=$ relevant enough, $4=$ relevant, and $5=$ very relevant. Experts considered the content of all 31 items were either relevant or very relevant, and suggested some improvements in wordings for more clarity.

The construct validity was ensured through the exploratory factor analysis (EFA). The exploratory analysis employed orthogonal rotation carried out with the varimax approach. The reliability of the instrument was estimated using coefficient alpha. Both analyses were performed using SPSS 23 for Windows.

\section{Findings and Discussion}

\section{Exploratory Factor Analysis}

Basically, similar to many previous studies, construct validity can be proven by employing confirmatory factor analysis (CFA) (Widdiharto, Kartowagiran, \& Sugiman, 2017) and or exploratory factor analysis (Clemens, Carey, \& Harrington, 2010). This study employed exploratory factor analysis (EFA) in order to explore the dimensions or factors in the instrument based on the empirically collected data (Kartowagiran, 2008, p. 188).

The results of initial check show that the instrument has the value of 0.89 in KaiserMeyer-Olkin (KMO) measure of sampling adequacy. This value is bigger than the minimum required score of 0.5 . The significance indicated by the value of sig. is $0.000<0.05$. All the values suggest that the data collected by using this physical abuse instrument were suitable for factor analysis. The next analysis involved factor extraction, factor rotation, interpretation of the result, reliability estimation, and naming the factors.

The purpose of factor extraction is 'to determine the number of initial subsets or factors that appear to represent the dimensions of the construct which is being measured'
(Pett, Lackey, \& Sullivan, 2003, p. 85). There are some factor extraction methods available for factor analysis, and some of them have been available in statistical soft wares such as Statistical Package for the Social Sciences (SPSS) or Statistical Analysis System (SAS). This article prefers the principal component analysis (PCA) to other methods, although some methodologists are not convinced of the use of PCA for various reasons. Costello and Osborne (2005, p. 2), for example, write 'component analysis is only a data reduction method', and it does not 'regard to any underlying structure caused by latent variables', etc.

Although many criticisms stand against the use of principal component analysis, Kline (2008, p. 74) sees that 'principle factor analysis seems to be a sensible choice' in factor analysis. Besides, the use of principle component analysis is the most popular one probably due to the fact that some statistics software packages use it as their default (Costello \& Osborne, 2005, p. 2), and also its result is easier to interpret compared to other methods (Pett et al., 2003, p. 102).

There are some common approaches to determination of the number of extracted factors to be retained (Fabrigar \& Wegener, 2012, pp. 53-67). This study, however, applied three of them which were considered to be the most common procedures, namely, eigenvalues greater than 1, percentage of variance explained, and the use of scree plot. These methods are the most frequently used in determining factor solution in the form of unrotated factor solutions. Although these approaches sometimes 'do not provide meaningful and easily interpretable clusters of items' (Pett et al., 2003, p. 131), they are most commonly used in the stage of factor extraction before processing factor rotation.

One of the results of factor extraction is table of Total Variance Explained. In this study (see Table 1), the formation of seven factors or components with eigenvalues $>1$. Factor one has the eigenvalue of 7.550, factor two has the eigenvalue of 1.983 , and factor three has eigenvalue of 1.827 . The fourth factor has the eigenvalue of 1.528 , the fifth factor has 1.218, sixth factor has 1.064, and the 
Table 1. Total variance explained in seven-factor model

\begin{tabular}{|c|c|c|c|c|c|c|c|c|c|}
\hline \multirow{2}{*}{ Component } & \multicolumn{3}{|c|}{ Initial Eigenvalues } & \multicolumn{3}{|c|}{$\begin{array}{c}\text { Extraction Sums of Squared } \\
\text { Loadings }\end{array}$} & \multicolumn{3}{|c|}{$\begin{array}{c}\text { Rotation Sums of Squared } \\
\text { Loadings }\end{array}$} \\
\hline & Total & $\begin{array}{c}\% \text { of } \\
\text { Variance }\end{array}$ & $\begin{array}{c}\text { Cumulative } \\
\%\end{array}$ & Total & $\begin{array}{c}\% \text { of } \\
\text { Variance }\end{array}$ & $\begin{array}{c}\text { Cumulative } \\
\%\end{array}$ & Total & $\begin{array}{c}\% \text { of } \\
\text { Variance }\end{array}$ & $\begin{array}{c}\text { Cumulative } \\
\%\end{array}$ \\
\hline 1 & 7.550 & 24.354 & 24.354 & 7.550 & 24.354 & 24.354 & 3.783 & 12.203 & 12.203 \\
\hline 2 & 1.983 & 6.395 & 30.749 & 1.983 & 6.395 & 30.749 & 2.913 & 9.398 & 21.601 \\
\hline 3 & 1.827 & 5.894 & 36.643 & 1.827 & 5.894 & 36.643 & 2.700 & 8.708 & 30.309 \\
\hline 4 & 1.528 & 4.929 & 41.572 & 1.528 & 4.929 & 41.572 & 2.129 & 6.868 & 37.177 \\
\hline 5 & 1.218 & 3.928 & 45.499 & 1.218 & 3.928 & 45.499 & 1.801 & 5.808 & 42.985 \\
\hline 6 & 1.064 & 3.431 & 48.931 & 1.064 & 3.431 & 48.931 & 1.528 & 4.928 & 47.913 \\
\hline 7 & 1.019 & 3.286 & 52.216 & 1.019 & 3.286 & 52.216 & 1.334 & 4.303 & 52.216 \\
\hline 8 & .978 & 3.156 & 55.372 & & & & & & \\
\hline 9 & .917 & 2.958 & 58.331 & & & & & & \\
\hline 10 & .888 & 2.865 & 61.196 & & & & & & \\
\hline 11 & .843 & 2.719 & 63.915 & & & & & & \\
\hline 12 & .800 & 2.581 & 66.496 & & & & & & \\
\hline 13 & .790 & 2.549 & 69.045 & & & & & & \\
\hline 14 & .759 & 2.448 & 71.493 & & & & & & \\
\hline 15 & .720 & 2.322 & 73.815 & & & & & & \\
\hline 16 & .665 & 2.146 & 75.961 & & & & & & \\
\hline 17 & .653 & 2.107 & 78.069 & & & & & & \\
\hline 18 & .628 & 2.026 & 80.095 & & & & & & \\
\hline 19 & .610 & 1.967 & 82.062 & & & & & & \\
\hline 20 & .587 & 1.893 & 83.955 & & & & & & \\
\hline 21 & .562 & 1.813 & 85.769 & & & & & & \\
\hline 22 & .534 & 1.721 & 87.490 & & & & & & \\
\hline 23 & .527 & 1.700 & 89.190 & & & & & & \\
\hline 24 & .509 & 1.641 & 90.831 & & & & & & \\
\hline 25 & .484 & 1.561 & 92.392 & & & & & & \\
\hline 26 & .475 & 1.531 & 93.923 & & & & & & \\
\hline 27 & .433 & 1.395 & 95.318 & & & & & & \\
\hline 28 & .391 & 1.261 & 96.580 & & & & & & \\
\hline 29 & .376 & 1.213 & 97.793 & & & & & & \\
\hline 30 & .368 & 1.186 & 98.979 & & & & & & \\
\hline 31 & .317 & 1.021 & 100.000 & & & & & & \\
\hline
\end{tabular}

Extraction Method: Principal Component Analysis.

seventh factor has 1.019. Using this procedure, the number of components with eigenvalues $>1$ would be counted as the number of the extracted factors which later are specified into the model (Fabrigar \& Wegener, 2012, p. 55).

The second approach is the percentage of variance explained by each component. The table of total variance explained shows seven components, each of which has different values of the variance explained. Component one accounted for $24 \%$ of variance, component two accounted for $6.3 \%$ of variance, factor three explained $5.8 \%$ of the variance. The rest four factors explained $4.929 \%$, $3.928 \%, 3.431 \%$, and $3.286 \%$ consecutively of the variance. This seven-factor model solution explained $52.216 \%$ of the variance in the table.

The last approach used to determine the number of extracted factors was scree plot (see Figure 1). The scree test basically exam- ines 'the graph of the eigenvalues and looking for the natural bend or breaks point in the data where the curve flattens out' (Costello \& Osborne, 2005, p. 3). Although the interpretation of the scree plot is subjective in nature (Fabrigar \& Wegener, 2012, p. 58; Kline, 2008 , p. 75), Gorsuch proposes scree plots over the Eigen-value $>1$ as the criteria (Pett et al., 2003, p. 120). With reference to that criterion, it is difficult to assume the formation of seven factors, since only four factors have eigenvalues $>1$.

In terms of the variance explained, although many researchers stop the factor extraction process when the total variance explained reaches $50-80 \%$, there are no definite guidelines for a particular threshold (Pett et al., 2003, p. 116). Hair et al. (1995) give criteria of the last factor no less than $5 \%$ of the explained variance (Pett et al., 2003, p. 116). Although it is intended for natural science, in this study, it is quite relevant as can be seen in 


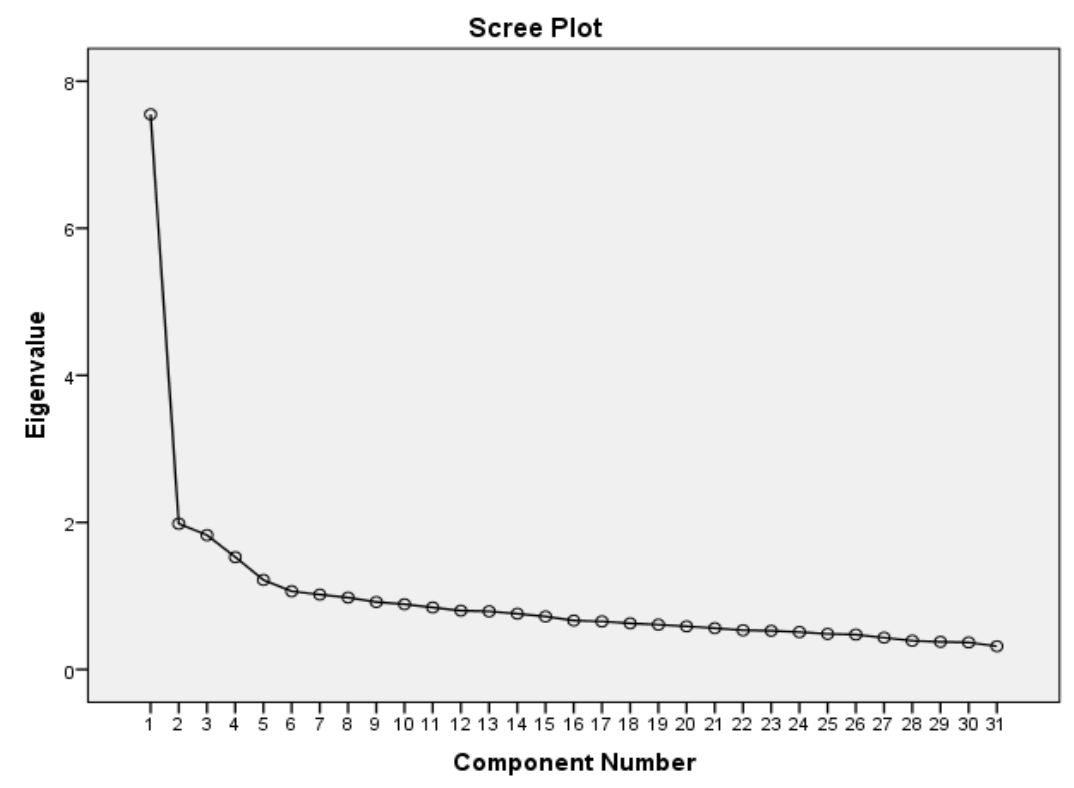

Figure 1. Scree plot of seven-factor model

the rest of this article. By applying that criterion to the above seven-factor model, it appeared that only the first three factors met the $5 \%$ criterion, despite the fact that seven factors had eigenvalue $>1$. Another problem was that the scree plot of this seven-factor model also could not show clearly the appearance of seven factors, instead, it showed only four factors. Using a straight line drawn with a ruler through the lower values of the plotted eigenvalues, it identified only four factors formed above the line.

Dealing with the inconsistent outcomes of the above three approaches in determining the number of factors, and the difficulties in interpreting their results, like many other researchers, we relied on rotation to improve the meaningfulness and to have better interpretation of the factors generated. This study used orthogonal rotation carried out with the varimax approach. Varimax maximizes the variances of the loading in the factors.

The results of the factor rotation are component matrix and rotated component matrix. In component matrix, all factor loadings of each item in each factor are shown without discriminating them based on high loadings only. Consequently, it includes all items-to-factor correlations. It, therefore, becomes overwhelming and rather difficult to interpret. In rotated component matrix, only high loading factors appear in each factor or component. At this point, a researcher can decide the value of factor loading allowed in the factor solution. In our seven-factor model, following Sadtyadi and Kartowagiran (2014, p. 295), we suppressed the absolute values of factor loadings to less than 0.50 and maintained $>0.5$. This helped to provide only high factor loadings $(>0.5)$ in each item. As a result, the loadings appeared were not overwhelming. Pedhazur and Schmelkin state that ideally, each item has high and meaningful factor loading on one factor only and each factor has high or meaningful loadings for only some of the items (quoted in Pett et al., 2003, pp. 132-133).

The output of the rotated solution clearly showed that items were grouped into seven components or factors. Except for three items with loadings factor less than 0.5, the items were distributed to seven components or factors. There was no crossloading item in this solution but several problems occurred. The first problem emerged because some different items carrying different conceptual meanings were grouped together, particularly in components 4 and 5 . In terms of conceptual inappropriateness, some items were loaded on irrelevant factors or, in other words, some items failed to load on conceptually appropriate factors. This was considered as an indication of incorrect factor structure (Costello \& Osborne, 2005, p. 5). 
The second problem came to light from the fact that two components, 6 and 7, were supported only by 2 and 1 items consecutively. Costello and Osborne (2005, p. 5) state that 'a factor with fewer than three items is generally weak and unstable'.

The unsatisfying appearance of the seven-factor solution led us to seek other solution which was expected to be meaningful conceptually and easy to interpret. Looking back to some indications shown in the sevenfactor model, particularly in the rotated component matrix, only the first three components or factors were easy to interpret and turned up to be conceptually more appropriate. In addition, by using the $5 \%$ criteria of variance extracted proposed by Hair et al (Pett et al., 2003, pp. 116-118), we found only three first factors met the criterion of $5 \%$. This is a strong indication of the existence of a three-factor solution.

In addition, we also linked this indication of three factors to the initial constructs in the physical abuse questionnaire and mapped the main issues in it. The instrument, in fact, contains three main issues i.e. abuse committed by teachers to respondents, abuse committed by fellow students to respondents, and abuse committed by the respondents of the survey to their fellow students. From these considerations, the factor analysis with three factors to extract was conducted. The lowest factor loading allowed was also determined to $\geq 0.40$ by suppressing the items that have factor loadings of less than 0.40 .

The results showed that the three-factor analysis met the $5 \%$ criterion for each factor (as proposed by Hair in earlier discussion). The variance explained by the three factors, however, was only $36.643 \%$, lower than the variance explained by the seven-factor model. To solve this low variance explained, we tried to accommodate more items by cutting down the lowest factor loading to 0.30 . The solution resulted from that decision, however, became more difficult to interpret. The analysis, therefore, was dragged back to $\geq 0.40$. With this threshold, the result revealed that the loadings of some four items disappeared due to having factor loadings of less than 0.40 and three items loaded in inappropriate factors (this was fewer than the number of items loaded in inappropriate factors in the seven-factor model). Those problematic seven items were then eliminated. Therefore, the number of items declined from 31 to 24 items.

After dropping these problematic items, we changed the sampling adequacy measured by Kaiser-Meyer-Olkin (KMO) into 0.891. The Barlett's test was still significant $0.000<$ 0.5 . The elimination of some items did not give negative impact on the data as a whole because both values of $\mathrm{KMO}$ and significance indicated that the data were suitable for factor analysis. The decision to eliminate those problematic items, in fact, improved the factor structure given that the variance explained increased from $36.643 \%$ to $41.428 \%$.

Another effect of eliminating some problematic items was that the number of the factors with eigenvalues $>1$ decreased to five factors (previously seven factors). Although the decreased number of factors was accompanied by an increase in variance explained, the criterion of determining the number of factors to retain was based more on the criterion that the factor has no less than $5 \%$ accounted for variance as proposed by Hair et al (Pett et al., 2003, p. 116). Besides, the appearance of the scree plot and theoretical considerations of the original constructs contained in the questionnaire were also the basis for our decision. With regard to the criterion of $>$ $5 \%$, the data in Table 2 clearly show the formation of three factors.

In terms of the $5 \%$ criterion, the three model solutions prove that only the first three factors have higher than $5 \%$ of the variance extracted. Factor one accounts for 26.288\% of variance and has an eigenvalue of 6.309, factor two accounts for $8.016 \%$ of the variance and its eigenvalue is 1.924 , and the third factor's eigenvalue is 1.710 and it accounts for $7.123 \%$ of the variance. The fourth and fifth factors, although have eigenvalues of 1.165 and 1.050 respectively, which are higher than 1 , each of their contributions to the explained variance is only $4.853 \%$ and $4.374 \%$, less than $5 \%$. These lead to their exclusion from the factors retained. As a whole, the three factors account for $41.428 \%$ of variance. 
Table 2. Total variance explained in three-factor model

\begin{tabular}{|c|c|c|c|c|c|c|c|c|c|}
\hline \multirow{2}{*}{ Component } & \multicolumn{3}{|c|}{ Initial Eigenvalues } & \multicolumn{3}{|c|}{$\begin{array}{c}\text { Extraction Sums of Squared } \\
\text { Loadings }\end{array}$} & \multicolumn{3}{|c|}{$\begin{array}{c}\text { Rotation Sums of Squared } \\
\text { Loadings }\end{array}$} \\
\hline & Total & $\begin{array}{c}\% \text { of } \\
\text { Variance }\end{array}$ & $\begin{array}{c}\text { Cumulative } \\
\%\end{array}$ & Total & $\begin{array}{c}\% \text { of } \\
\text { Variance }\end{array}$ & $\begin{array}{c}\text { Cumulative } \\
\%\end{array}$ & Total & $\begin{array}{c}\% \text { of } \\
\text { Variance }\end{array}$ & $\begin{array}{c}\text { Cumulative } \\
\%\end{array}$ \\
\hline 1 & 6.309 & 26.288 & 26.288 & 6.309 & 26.288 & 26.288 & 4.038 & 16.823 & 16.823 \\
\hline 2 & 1.924 & 8.016 & 34.305 & 1.924 & 8.016 & 34.305 & 3.004 & 12.518 & 29.341 \\
\hline 3 & 1.710 & 7.123 & 41.428 & 1.710 & 7.123 & 41.428 & 2.901 & 12.087 & 41.428 \\
\hline 4 & 1.165 & 4.853 & 46.281 & & & & & & \\
\hline 5 & 1.050 & 4.374 & 50.655 & & & & & & \\
\hline 6 & .937 & 3.904 & 54.559 & & & & & & \\
\hline 7 & .884 & 3.683 & 58.243 & & & & & & \\
\hline 8 & .851 & 3.545 & 61.788 & & & & & & \\
\hline 9 & .807 & 3.362 & 65.150 & & & & & & \\
\hline 10 & .781 & 3.253 & 68.403 & & & & & & \\
\hline 11 & .740 & 3.082 & 71.485 & & & & & & \\
\hline 12 & .690 & 2.876 & 74.361 & & & & & & \\
\hline 13 & .634 & 2.640 & 77.001 & & & & & & \\
\hline 14 & .608 & 2.532 & 79.533 & & & & & & \\
\hline 15 & .598 & 2.494 & 82.027 & & & & & & \\
\hline 16 & .581 & 2.419 & 84.446 & & & & & & \\
\hline 17 & .570 & 2.375 & 86.821 & & & & & & \\
\hline 18 & .529 & 2.206 & 89.027 & & & & & & \\
\hline 19 & .522 & 2.175 & 91.201 & & & & & & \\
\hline 20 & .489 & 2.036 & 93.238 & & & & & & \\
\hline 21 & .440 & 1.831 & 95.069 & & & & & & \\
\hline 22 & .435 & 1.811 & 96.881 & & & & & & \\
\hline 23 & .378 & 1.574 & 98.454 & & & & & & \\
\hline 24 & .371 & 1.546 & 100.000 & & & & & & \\
\hline
\end{tabular}

Extraction Method: Principal Component Analysis.

Another method which is used to help making decision on the number of factor to keep is scree plot. Although some methodologists criticize the use of scree plot (Fabrigar, Wegener, Maccallum, \& Strahan, 1999, pp. 278-279), it is one of the most widely used approaches in the exploratory factor analysis. Costello and Osborne (2005, p. 3) even state that 'the best choice for researchers is the scree test'. It is admitted that one of main problems related to the use of scree plot is that researchers tend to use their subjective nature in interpreting them. Some researchers, however, provide guidelines. Costello and Osborne (2005, p. 3) assert that 'the number of data points above the "break" (i.e., not including the point at which the break occurs) is usually the number of factors to retain'. Pett et al. (2003, p. 119) advise 'that point where the factors curve above the straight line drawn [with a ruler] through the smaller eigenvalues identifies the number of factors'. The scree plot presented in Figure 2 is an output based on the data processed through SPSS package.

Following the afore-mentioned guidelines of interpreting scree plot, the scree plot presented in Figure 2 clearly presents three factors above the break or above the straight line drawn from the lowest eigenvalue horizontally. In other words, the scree output shows a similar result with the $5 \%$ criterion and is also relevant to the original constructs containing three main themes in the questionnaire of physical abuses. Except for the criteria of eigenvalues $>1$, all of these other criteria confirm the formation of three-factor solution model in the factor extraction.

The decision to involve theoretical considerations or original construct in determining the number of factors to retain referred to the recommendations provided by Nunnally and Bernstein (1994) paraphrased by Pett et al. (2003, p. 125) as follows:

How many factors should we extract... two... three... four? There is no easy solution to this decision. Nunnally and Bernstein (1994) caution the researcher against using rigid guidelines for determining the ultimate number of factors to extract. Whatever solution we arrive at should not be solely based on statistical criteria; it also needs to make theoretical sense. The ultimate criteria for determining the number of factors are factor interpretability and usefulness both during the initial extraction procedures and after the factors have been rotated to achieve more clarity. 


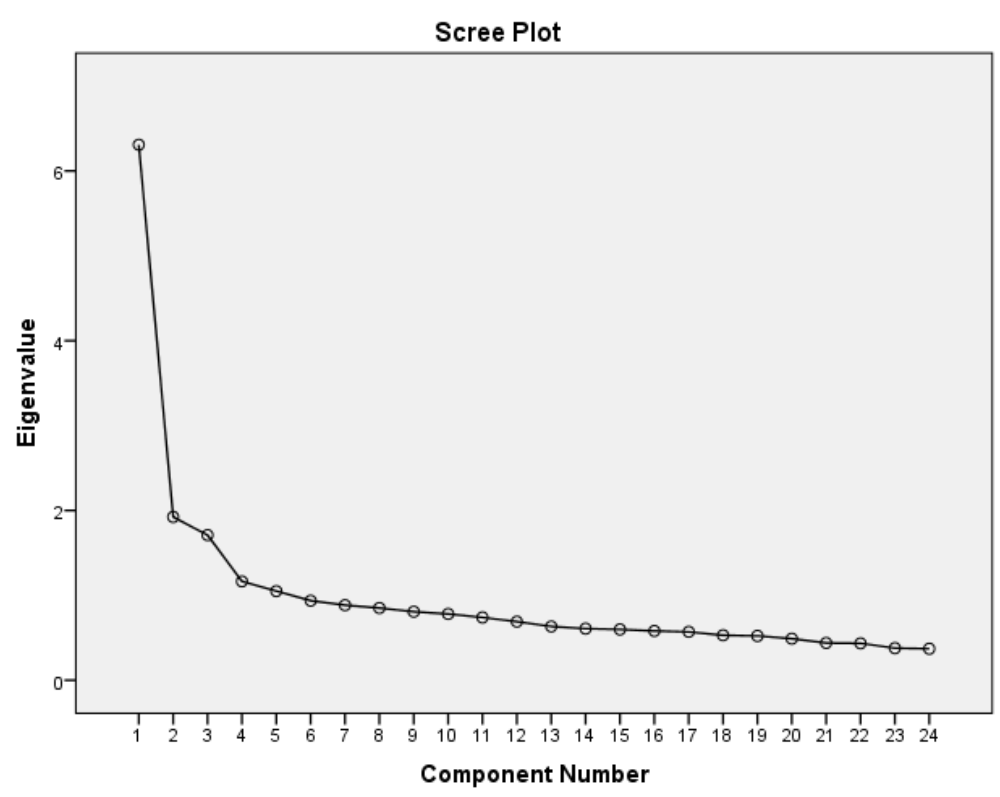

Figure 2. Scree plot of three-factor model

It was the purpose to reach factor interpretability and usefulness that led us to involve our original construct in determining the factors beside statistical inputs. The purpose also became the basis for repeatedly refining the solution and examine them to find a more suitable solution which best explained the data and disclosed the structure of constructs behind the measurable variables. The use of orthogonal rotation with varimax had generated factor loading matrix in which the items were grouped together neatly to each factor. This is, therefore, more interpretable.

There are two things worth noting here. First, the requirement of adequate numbers of items load in each factor is fulfilled. Referring to views proposed by Nunnally and Bernstein (1994), Pett et al. (2003, p. 125) write if the extracted factors serve to describe characteristics that variables have in common, then, by definition, there need to be at least two items for each extracted factor'. Further, Costello and Osborne (2005, p. 3) propose at least three items for each factor. Second, the factor loadings of the items ranging from 0.44 to 0.69 are good enough and even very good (Comrey \& Lee, 2009, p. 243). The detailed illustration of the matrix of factor structure and item loadings can be found in Table 3 .

There are some guidelines to interpret the construct validity of this instrument based on the information presented in the factor structure matrix. Some researchers employ factor loading of each item $\geq 0.30$ (McCauley, Ruderman, Ohlott, \& Morrow, 1994, p. 548). Comrey and Lee (2009, p. 243) propose higher than 0.30 , by saying "whereas loadings of 0.30 and above have commonly been listed among those high enough to provide some interpretive value, such loadings certainly cannot be relied upon to provide a very good basis for factor interpretation'. In addition, some even use factor loading $>0.50$ (Kartowagiran \& Jaedun, 2016, p. 133; Wijanto, 2008, p. 193).

According to Costello and Osborne (2005, p. 3), item loading table 'has the best fit to data' if item loadings above 0.30 , no or few items cross-loadings, and no factors with fewer than three items. To meet those criteria, this study uses factor loading $\geq 0.40$. In more detail, out of 24 valid items with factor loadings above $0.40,14$ of them are $>0.60$, six are $>0.50$, and the rest four items are $>0.40$. There is no cross-loading item in the matrix which means each item is unidimensional. In addition, there are more than three items load in each factor. Due to all requirements proposed by the above methodologists, which were fulfilled well, it can be confidently affirmed that the construct validity of this instrument has been reached satisfactorily. 
Table 3. Factor loading matrix of physical abuse experience among school students

\begin{tabular}{|c|c|c|c|c|}
\hline No & Item Wordings & Factor 1 & Factor 2 & Factor 3 \\
\hline Fisik17 & Has any student pushed your body or head harshly? & .690 & & \\
\hline Fisik11 & $\begin{array}{l}\text { Has any student hit you by using any blunt objects (examples: wood, } \\
\text { rattan, or others)? }\end{array}$ & .688 & & \\
\hline Fisik16 & Has any student tweaked your ears? & .662 & & \\
\hline Fisik13 & $\begin{array}{l}\text { Has any student thrown something solid at you? (such as book or other } \\
\text { stuff) }\end{array}$ & .646 & & \\
\hline Fisik10 & Has any student slapped you? & .622 & & \\
\hline Fisik15 & Has any student pulled your hair harshly? & 607 & & \\
\hline Fisik14 & Has any student pinched you because he/she got angry to you? & .581 & & \\
\hline Fisik12 & Has any student kicked you? (not in a jock or sport). & .555 & & \\
\hline Fisik18 & Has any student injured you? & .468 & & \\
\hline Fisik19 & Has any student scratched you? & .441 & & \\
\hline Fisik30 & Have you scratched other students? & & .665 & \\
\hline Fisik31 & Have you bitten other students? & & .658 & \\
\hline Fisik26 & Have you pulled another student's hair harshly? & & .627 & \\
\hline Fisik27 & Have you tweaked another student's ears? & & .548 & \\
\hline Fisik25 & Have you pinched other students because you are angry to him/her? & & .529 & \\
\hline Fisik28 & Have you pushed other student's body or head harshly? & & .528 & \\
\hline Fisik29 & Have you injured other students? & & .499 & \\
\hline Fisik24 & $\begin{array}{l}\text { Have you thrown something solid at other students (such as book or other } \\
\text { stuff) }\end{array}$ & & .452 & \\
\hline Fisik5 & Has your teacher pinched you because he/she is angry? & & & .687 \\
\hline Fisik2 & $\begin{array}{l}\text { Has your teacher hit you by using any blunt objects (examples: wood, } \\
\text { rattan, or others)? }\end{array}$ & & & .676 \\
\hline Fisik8 & $\begin{array}{l}\text { Has any teacher punished you by asking you to position your body in a way } \\
\text { that made you are physically unpleasant? }\end{array}$ & & & .636 \\
\hline Fisik7 & Has your teacher tweaked your ears? & & & .632 \\
\hline Fisik1 & Has your teacher hit or slapped you? & & & .628 \\
\hline Fisik4 & Have your teachers thrown something (such as book or other stuff) at you? & & & .578 \\
\hline
\end{tabular}

Extraction Method: Principal Component Analysis.

Rotation Method: Varimax with Kaiser Normalization.

a. Rotation converged in 5 iterations.

Usually, the factor's name is drawn from the name of the item with the highest factor loading. In the case of this study, however, it is much easier to give the name since the items grouped in each factor have some common themes. Ten items that load on factor 1 appear to have one common theme in spite of having different contents from one another. Every item contains a specific act of abuse such as pushing body, hitting, and tweaking, but all refer to the same topic, that is, abuse committed by fellow students. In factor 2, each of the eight items deals with specific content, but the main theme assembling the items' similarities within this factor is that the persecutors committing the abuse are the respondents who abuse other students. With the same pattern of interpretation, the six items loaded in factor 3 hold the same common theme, apart from their differences, namely abuse committed by school teachers.
Based on the mapping of the common themes reflected by the groups of items in each factor, it is reasonable to name the first factor containing items on abuses by fellow students as victimized by friends, the second factor covering items on abuses by respondents towards other students as victimizing friends, and the third factor carrying items containing abuses by teachers as being victimized by teachers. These names become new identities of each factor while the identity of each item is not important anymore. These identities, according to Kachigan, can be used to communicate to other people who are interested in using the instrument for their own research or in applying the results of the studies that have used the instrument (Pett et al., 2003, p. 210).

\section{Reliability}

Beside instrument validity, the instrument reliability is also important to estimate. Reliability test is part of instrument construc- 
tion to make sure the instrument composed by the retained factors has good internal consistency. Reliability helps to know to what extent an instrument is free from measurement error.

In order to ensure the reliability of an instrument that has some subscales (factors), some methodologists and also researchers emphasize to estimate the coefficient alpha of each factor or subscale (Amir, 2015, p. 227; Pett et al., 2003, p. 188). Other methodologists, however, recommended to estimate the reliability of each scale as well as the entire scale. Parsian and AM (2009, p. 5), referring to Nunally and Bernstein (1994) and DeVon et al (2007), state that if an instrument contains two or more subscales, Cronbach's alpha should be computed for each subscale as well as the entire scale.' For this reason, in order to estimate the instrument reliability of the student's experience of physical abuses in school, first, the researchers generated the coefficient alpha for the whole items involving the three factors together, entire scale, then we generated coefficient alphas of each of the three derived factors independently. The lowest but still acceptable reliability coefficient used here is $\geq 0.65$ (Cohen \& Swerdlik, 2009, p. 151; Nurmin \& Kartowagiran, 2013, p. 189).

The result of the reliability estimation shows that the reliability for the overall physical abuse scale (when the 24 items combined) is 0.874 , which is satisfactory. Coefficient alpha will not be significantly affected by any drop of item. If any item were deleted, the coefficient of the entire scale would remain higher than 0.80. Coefficient alpha for factor one with the whole 10 items is 0.830 . This is stable since any removal of any item will not seriously affect the coefficient for the reason that coefficient will remain above 0.80 . Factor two with eight items has 0.735 coefficient alpha, and Cronbach's Alpha of factor three is 0.766 . In short, the reliability estimation shows that both entire scale and each subscale of the instrument have a good reliability coefficient.

\section{Conclusion and Suggestions}

The exploration of construct of physical abuse or violence against children in schools and the development of instrument for measuringsuch abuse have revealed three factors behind the construct: (1) victimized by friends, (2) victimizing friends, and (3) being victimized by teachers. The factor loadings of the items grouped in the victimized by friends factor range from 0.44 to 0.69 . The item loads in the victimizing friends factor have loadings ranging from 0.45 to 0.66 . The items included in the factor of being victimized by teachers have factor loadings ranging from 0.57 to 0.68. All of these prove that this instrument has good construct validity.

The reliability of the instrument was estimated through Cronbach's Alpha coefficient. It is categorized as good since the reliability coefficient of the first factor is 0.830 , that of the second factor is 0.735 , and that of the third factor is 0.766 . The Alpha coefficient of the entire instrument is 0.874 . In short, the final result of this instrument development is the formation of an instrument for measuring students' experience of physical abuse in schools, which consists of three factors with 24 items, and it has good validity and reliability.

By providing this instrument for measuring physical abuse experienced by students in schools, any researchers who are interested in studying student's experience of physical abuse in schools can use this instrument. Likewise, those who want to evaluate policies concerning child-friendly schools or any related policies on the subject of preventing physical abuse in schools can make use of this instrument. Furthermore, this is also open for those who want to confirm this instrument through further analysis using the confirmatory factor analysis (CFA).

\section{References}

Ajema, C., Muraya, K., Karuga, R., \& Kiruki, M. (2016). Childhood experience of abuse in Kajiado County-Kenya. Kenya: LVTC Health.

Amir, M. T. (2015). Merancang kuesioner: Konsep dan panduan untuk penelitian sikap, kepribadian, dan perilaku. Jakarta: Prenada Media Group.

Choo, W.-Y., Dunne, M. P., Marret, M. J., 
Fleming, M., \& Wong, Y.-L. (2011). Victimization experiences of adolescents in Malaysia. Journal of Adolescent Health, 49(6), 627-634. https://doi.org/ 10.1016/j.jadohealth.2011.04.020

Clark, R. E., Clark, J. F., \& Adamec, C. A. (2007). The encyclopedia of child abuse (3rd ed.). New York, NY: Facts on File Library of Health and Living.

Clemens, E. V, Carey, J. C., \& Harrington, K. M. (2010). The school counseling program implementation survey: Initial instrument development and exploratory factor analysis. Professional School Counseling, 14(2), 125-134.

Cohen, R. J., \& Swerdlik, M. (2009). Psychological testing and assessment: An introduction to test and measurement. New York, NY: McGraw-Hill.

Cohn, A., \& Canter, A. (2003). Bullying: Facts for schools and parents. Retrieved from http://www.naspcenter.org/factsheets/ bullying_fs.html

Comrey, A. L., \& Lee, H. B. (2009). A first course in factor analysis (2nd ed.). New York, NY: Psychology Press.

Costello, A. B., \& Osborne, J. W. (2005). Best practices in exploratory factor analysis: Four recommendations for getting the most from your analysis. Practical Assessment, Research \& Evaluation, 10(7), 1-9.

Fabrigar, L. R., \& Wegener, D. T. (2012). Exploratory factor analysis. Oxford: Oxford University Press.

Fabrigar, L. R., Wegener, D. T., Maccallum, R. C., \& Strahan, E. J. (1999). Evaluating the use of exploratory factor analysis in psychological research. Psychological Methods, 4(3), 272-299.

Hyman, I. A., \& Perone, D. C. (1998). The other side of school violence: Educator policies and practices that may contribute to student misbehavior. Journal of School Psychology, 36(1), 7-27.

Idris, F. (2015, December 30). 2015, tahun buram kekerasan anak. Republika.
Retrieved from https://www.republika. co.id/berita/koran/opini-koran/15/12/ 30/o05vk812-2015-tahun-buram-

kekerasan-anak

Kartowagiran, B. (2008). Validasi dimensionalitas perangkat tes ujian akhir nasional SMP mata pelajaran matematika 2003-2006. Jurnal Penelitian Dan Evaluasi Pendidikan, 12(2), 177-195. https://doi. org/10.21831/pep.v12i2.1426

Kartowagiran, B., \& Jaedun, A. (2016). Model asesmen autentik untuk menilai hasil belajar siswa sekolah menengah pertama (SMP): Implementasi asesmen autentik di SMP. Jurnal Penelitian Dan Evaluasi Pendidikan, 20(2), 131-141. https://doi. org/10.21831/pep.v20i2.10063

Kline, P. (2008). An easy guide to factor analysis. New York, NY: Routledge.

Law No. 35 of 2014 of Republic of Indonesia concerning Amendments to Law No. 3 of 2002 concerning Child Protection (2014).

McCauley, C. D., Ruderman, M. N., Ohlott, P. J., \& Morrow, J. E. (1994). Assessing the developmental components of managerial jobs. Journal of Applied Psychology, 79(4), 544-560. https:// doi.org/10.1037/0021-9010.79.4.544

Muthmainnah, M. (2014). Membekali anak dengan keterampilan melindungi diri. Jurnal Pendidikan Anak, 3(1). Retrieved from https://journal.uny.ac.id/index.ph $\mathrm{p} / \mathrm{jpa} /$ article/view/3053

Nansel, T. R., Overpeck, M., Pilla, R. S., Ruan, W. J., Simons-Morton, B., \& Scheidt, P. (2001). Bullying behaviors among US youth: Prevalence and association with psychosocial adjustment. JAMA, 285(16), 2094-2100.

NSPCC. (2016). What children are telling us about bullying. Child Bullying Report 2015/2016.

Nurmin, N., \& Kartowagiran, B. (2013). Evaluasi kemampuan guru dalam mengimplementasi pembelajaran tematik di SD kecamatan Salahutu Kabupaten Maluku Tengah. Jurnal Prima Edukasia, 
1(2), 184-194. https://doi.org/ 10.21831/JPE.V1I2.2635

Parsian, N., \& AM, T. D. (2009). Developing and validating a questionnaire to measure spirituality: A psychometric process. Global Journal of Health Science, 1(1), 2-11. https://doi.org/ $10.5539 /$ gjhs.v1n1p2

Pett, M. A., Lackey, N. R., \& Sullivan, J. J. (2003). Making sense of factor analysis: The use of factor analysis for instrument development in health care research. Thousand Oaks, CA: Sage Publications.

Qodar, N. (2015, March 15). Survei ICRW: $84 \%$ anak Indonesia alami kekerasan di sekolah. Liputan6.Com. Retrieved from https://www.liputan6.com/news/read/ 2191106/survei-icrw-84-anak-indonesiaalami-kekerasan-di-sekolah

Rivers, I., \& Smith, P. K. (1994). Types of bullying behaviour and their correlates. Aggressive Behavior, 20(5), 359-368.

Sadtyadi, H., \& Kartowagiran, B. (2014). Pengembangan instrumen penilaian kinerja guru sekolah dasar berbasis tugas pokok dan fungsi. Jurnal Penelitian Dan Evaluasi Pendidikan, 18(2), 290-304. https://doi.org/10.21831/pep.v18i2.286 7

Setyawan, D. (2015, June 14). KPAI: Pelaku kekerasan terhadap anak tiap tahun meningkat. Komisi Perlindungan Anak Indonesia (KPAI). Retrieved from http://www.kpai.go.id/berita/kpaipelaku-kekerasan-terhadap-anak-tiaptahun-meningkat

Setyawan, D. (2017, November 23). Kekerasan anak di sekolah semakin memprihatinkan. Komisi Perlindungan Anak Indonesia (KPAI). Retrieved from http://www.kpai.go.id/berita/kekerasan -anak-di-sekolah-semakinmemprihatinkan

Simpson, S. B. (2015). Bullying perceptions: Understanding students with and without disabilities. Retrieved from https:// mds.marshall.edu/cgi/viewcontent.cgi?r eferer $=\&$ httpsredir $=1 \&$ article $=1974 \&$ co ntext $=$ etd

Straus, M. A., Hamby, S. L., Boney-McCoy, S., \& Sugarman, D. B. (1996). The revised Conflict Tactics Scales (CTS2). Journal of Family Issues, 17(3), 283-316. https://doi.org/10.1177/019251396017 003001

Straus, M. A., Hamby, S. L., Finkelhor, D., Moore, D. W., \& Runyan, D. (1998). Identification of child maltreatment with the parent-child conflict tactics scales: Development and psychometric data for a national sample of American parents. Child Abuse \& Neglect, 22(4), 249-270. https://doi.org/10.1016/S01452134(97)00174-9

UNICEF. (2014a). Measuring violence against children: Inventory and assessment of quantitative studies. New York, NY: Division of Data, Research and Policy.

UNICEF. (2014b). Violence against children in East Asia and the Pacific: A regional review and synthesis of findings. Bangkok: UNICEF EAPRO.

United Nations Secretary-General's Study. (2006). Violence against children in schools and educational settings. Violence against children: United Nations Secretary-General's Study. Geneva. Retrieved from https://www.unicef.org/violencestudy/ 4. World Report on Violence against Children.pdf

Widdiharto, R., Kartowagiran, B., \& Sugiman, S. (2017). A construct of the instrument for measuring junior high school mathematics teacher's self-efficacy. Research and Evaluation in Education, 3(1), 64-76. https://doi.org/ 10.21831/reid.v3i1.13559

Wijanto, S. H. (2008). Structural equation modelling (SEM) dengan Lisrel 8.8. Yogyakarta: Graha Ilmu. 